\title{
Investigating rennet coagulation properties of recombined highly concentrated micellar casein concentrate and cream for use in cheese making
}

\author{
Y. Lu, D. J. McMahon, ${ }^{1}$ and A. H. Vollmer \\ Western Dairy Center, Department of Nutrition, Dietetics, and Food Sciences, Utah State University, Logan 84322-8700
}

\section{ABSTRACT}

Highly concentrated micellar casein concentrate (HC-MCC) contains $\sim 18 \%$ casein with $\sim 70 \%$ of whey proteins removed by microfiltration and diafiltration of skim milk, followed by vacuum evaporation for further concentration. When blended with cream, HC-MCC forms recombined concentrated milk (RCM), which could be used as a starting material in cheese making. Our objective was to investigate the rennet coagulation properties of RCM while varying parameters such as casein level, $\mathrm{pH}$, rennet level, and coagulation temperature. The HC-MCC was mixed with cream using low shear at $50^{\circ} \mathrm{C}$ for $10 \mathrm{~min}$, followed by cooling to 31,28 , or $25^{\circ} \mathrm{C}$ and adding rennet, and rheological properties were determined. Rennet coagulation time [RCT, the time at which storage modulus $\left(\mathrm{G}^{\prime}\right)=$ loss modulus $\left(G^{\prime \prime}\right)$ ] decreased from 8.7 to $7.4 \mathrm{~min}$ as casein level increased from 3.2 to $5.7 \%$, without a significant additional difference in RCT at casein levels $>5.7 \%$. The initial $\mathrm{G}^{\prime \prime}\left(\mathrm{G}_{0}{ }_{0}\right)$ increased about 10 -fold when casein levels were increased from 3.2 to $10.9 \%$, whereas no change in initial $\mathrm{G}^{\prime}\left(\mathrm{G}_{0}^{\prime}\right)$ was observed. When $\mathrm{G}^{\prime}$ was measured relative to RCT (i.e., 1, 1.5, or 2 times RCT after RCT was reached, and expressed as $\mathrm{G}_{1}^{\prime}, \mathrm{G}_{1.5}^{\prime}$, and $\mathrm{G}_{2}{ }_{2}$ ), $\log$ relationship was found between relative $\mathrm{G}^{\prime}$ and casein level $\left(\mathrm{R}^{2}>0.94\right)$. Lowering coagulation temperature from 31 to $25^{\circ} \mathrm{C}$ increased $\mathrm{G}^{\prime \prime}{ }_{0}$ by 6 fold and extended RCT from 7.4 to $9.5 \mathrm{~min}$. After coagulation, relative $\mathrm{G}^{\prime}$ was initially higher at the lower temperature with $\mathrm{G}_{1}^{\prime}$ of $3.6 \mathrm{~Pa}$ at $25^{\circ} \mathrm{C}$ and $2.0 \mathrm{~Pa}$ at $31^{\circ} \mathrm{C}$, but delayed in further development with $\mathrm{G}_{2}^{\prime}$ of $0.8 \mathrm{kPa}$ at $25^{\circ} \mathrm{C}$ and $1.1 \mathrm{kPa}$ at $31^{\circ} \mathrm{C}$. Lowering $\mathrm{pH}$ of $\mathrm{RCM}$ from 6.6 to 6.2 resulted in reduced RCT from 11.9 to 6.5 min with increased relative $\mathrm{G}^{\prime}$ after coagulation. When less rennet was used, RCT increased in a linear inverse relationship without changes in relative $\mathrm{G}^{\prime}$ or

Received June 21, 2016.

Accepted October 22, 2016

${ }^{1}$ Corresponding author: Donald.mcmahon@usu.edu
$\mathrm{G}^{\prime \prime}$. The microstructure of RCM coagulum $(\sim 11 \%$ casein), observed using transmission electron microscopy, confirmed that RCM curd had a rigid protein matrix containing extensively cross-linked protein strands.

Key words: microfiltration, micellar casein, microstructure, coagulation

\section{INTRODUCTION}

Cheese manufacturing using concentrated milk is typically performed in industry with milk that has been processed by UF to increase cheese yield and milk processing capacity (Ernstrom et al., 1980; Kosikowski et al., 1985; Govindasamy-Lucey et al., 2004). However, concentrating milk using microfiltration (MF) is potentially more suitable for cheese making compared with UF milk as it allows removal of whey proteins before cheese making. These could be used to manufacture milk-derived whey protein concentrates (Evans et al., 2009,2010 ) that have potentially higher value because of their stronger foaming ability, gel strength, solubility, and emulsifying ability than whey protein concentrates derived after cheese making (Burrington, 2013). The use of MF concentrated milk has been studied in the manufacture of Cheddar (St-Gelais et al., 1995; Neocleous et al., 2002a,b), Mozzarella (Garem et al., 2000; Brandsma and Rizvi, 2001), and cheese without a standard of identity (i.e., pizza cheese; GovindasamyLucey et al., 2007).

Through MF, diafiltration, and vacuum evaporation of skim milk, a highly concentrated micellar casein concentrate (HC-MCC; $\sim 20 \%$ wt/wt protein) can been manufactured that when mixed with cream forms recombined concentrated milk (RCM; Lu et al., 2015). Such RCM is potentially suitable for use in cheese making because it has low whey protein levels $(<2 \%$ wt/wt), which from a theoretical point of view should result in cheese texture and flavor that is more comparable to that obtained with whole milk. However, both HC-MCC and RCM undergo cold gelation if protein levels are too high, which greatly affect their use as food ingredients (Lu et al., 2015). This can be avoided 
during cheese making provided the casein content of $\mathrm{RCM}$ is no more than $12 \%$ ( $\mathrm{Lu}$ et al., 2016).

A challenge of cheese making using concentrated milk such as RCM is that as milk concentration increases, rennet coagulation time shortens, and both curd firming rate and curd hardness increase (Sharma et al., 1993; Orme, 1998). Having a harder coagulum causes problems of cutting using conventional cheese making machinery. Cheese making using highly concentrated milk $(\sim 7$ to $8 \times)$ requires specialized processing equipment, and thus it is not widely used in industry (Brandsma and Rizvi, 1999; Fox et al., 2000; Brandsma and Rizvi, 2001). Instead, cheese making using less concentrated milk (up to $1.8 \times$ ) is widely applied due to the convenience of not requiring specialized equipment or large changes in cheese making procedures (Neocleous et al., 2002a,b; Govindasamy-Lucey et al., 2004), and the negative effect of higher levels of UF concentration on cheese texture and flavor development (Creamer et al., 1987; Lelievre et al., 1990; Bastian et al., 1991) does not occur. Our objective was to characterize the rennet coagulation properties of RCM made by mixing HC-MCC with cream under varying conditions, such as casein level, rennet level, coagulation temperature, and $\mathrm{pH}$. Transmission electron microscopy was used to understand the microstructure of RCM before and after rennet addition.

\section{MATERIALS AND METHODS}

\section{HC-MCC and RCM}

The HC-MCC was manufactured at the Institute for Dairy Ingredient Processing at South Dakota State University (Brookings, SD) as described by $\mathrm{Lu}$ et al. (2015). In brief, pasteurized skim milk was concentrated to $\sim 12.5 \%$ solids using MF with diafiltration and then further condensed through vacuum evaporation to form HC-MCC. Frozen HC-MCC was shipped to Utah State University (Logan) and stored frozen until needed.

Table 1. Composition of highly concentrated micellar casein concentrate (HC-MCC) made using microfiltration and vacuum evaporation

\begin{tabular}{lrc}
\hline & \multicolumn{2}{c}{ HC-MCC } \\
\cline { 2 - 3 } Component & Batch I & Batch II \\
\hline TS (\%) & 30.14 & 27.04 \\
Fat (\%) & 0.94 & 0.67 \\
Total N (\%) & 23.02 & 18.63 \\
Noncasein N (\%) & 2.30 & 1.62 \\
NPN (\%) & 0.32 & 0.21 \\
Casein N/total N & 0.90 & 0.91 \\
Ash (\%) & 2.33 & 1.93 \\
Calcium (\%) & 0.72 & 0.54 \\
\hline
\end{tabular}

Compositions of 2 batches of HC-MCC are shown in Table 1.

One hundred gram aliquots of RCM were prepared by mixing thawed HC-MCC with cream $(32 \%$ to $44 \%$ fat; Aggie Creamery, Utah State University, Logan, or Dean Foods, Dallas, TX) that had been warmed to $50^{\circ} \mathrm{C}$ and skim milk (Dean Foods), in proportions necessary to achieve the desired casein level and protein:fat ratio as described by Lu et al. (2016). The RCM was mixed at low shear using a magnetic stirrer $(\sim 800 \mathrm{rpm})$ at $50^{\circ} \mathrm{C}$ for 10 min. Typically, RCM had a pH of 6.4 to 6.6. After cooling to $31^{\circ} \mathrm{C}$, adjustments to $\mathrm{pH}$ were made using $1 \mathrm{~N} \mathrm{HCl}$ or $\mathrm{NaOH}$ (J. T. Baker, Phillipsburg, NJ), and the RCM was tempered to the required temperature before renneting. Protein content of RCM was tested in triplicate using a rapid protein analyzer (Sprint, CEM, Matthews, NC).

Rheological Properties. For each rheological test (performed in triplicate), a 100-g aliquot of RCM was prepared with protein:fat ratio of 0.8 , and estimated casein levels of $3.2,5.7,8.4$, or $10.9 \%$; $\mathrm{pH} 6.2,6.4$, or 6.6 ; and tempered at 25,28 , or $31^{\circ} \mathrm{C}$. Pasteurized whole milk was also used as a control for comparison. Then 20 $\mu \mathrm{L}$ of double-strength [nominal 650 international milk clotting units (MCU)/mL] chymosin rennet (Maxiren, DSM Food Specialties, Eagleville, PA) diluted in $1 \mathrm{~mL}$ of distilled water was added, yielding test aliquots containing $130 \mathrm{MCU} / \mathrm{kg}$. In addition, for RCM containing $\sim 11 \%$ casein, varying amounts of chymosin were added to also produce test mixtures containing 33,44 , and 65 $\mathrm{MCU} / \mathrm{kg}$.

Immediately, $7.5 \mathrm{~mL}$ of renneted RCM or milk control was poured into the coaxial cylinder of a magnetic bearing rheometer (model AR-G2, TA Instruments, New Castle, DE) at the same temperature. Samples were covered with a solvent trap to prevent evaporation and a time sweep was performed using a strain of 0.01 and frequency of $1 \mathrm{~Hz}$. Based on the time from rennet addition, RCT was determined as the time when storage modulus $\left(\mathbf{G}^{\prime}\right)$ equaled loss modulus $\left(\mathbf{G}^{\prime \prime}\right)$. Measurements of gel development were continued until twice the RCT.

Transmission Electron Microscopy. An aliquot of RCM was prepared with $\sim 11 \%$ casein and casein:fat ratio of 0.8 and cooled to $31^{\circ} \mathrm{C}$ along with an aliquot of pasteurized whole milk (Aggie Creamery) with 3.1\% protein and standardized to protein:fat ratio of 0.8 as a control. Then, $5 \mathrm{~g}$ of RCM or milk was transferred to a $50-\mathrm{mL}$ test tube and mixed with $0.2 \mathrm{~mL}$ of $50 \%$ (wt/wt) glutaraldehyde (Electron Microscopy Services, Hatfield, PA) by gently inverting the tube several times and holding for $5 \mathrm{~min}$ at $31^{\circ} \mathrm{C}$ to chemically fix the protein. This was followed by addition of $5.2 \mathrm{~mL}$ of $3 \%$ (wt/wt) low-melting agarose (FMC BioProducts, 
Rockland, ME; at $\sim 50^{\circ} \mathrm{C}$ ) and thoroughly mixed by vortexing. The mixture was poured into a Petri dish to about 1-mm thickness, and allowed to solidify by cooling to room temperature $\left(\sim 22^{\circ} \mathrm{C}\right)$ for $20 \mathrm{~min}$. Small cubes $(\sim 1 \times 1 \times 1 \mathrm{~mm})$ were cut with a sharp razor blade and carefully transferred to a glass vial filled with $2 \%$ glutaraldehyde and stored at $4^{\circ} \mathrm{C}$ until samples were processed for TEM as described in Lu et al. (2015). Briefly, samples were washed, postfixed with $2 \%$ osmium tetroxide, en-bloc stained with saturated uranyl acetate, dehydrated in an ascending series of ethanol, infiltrated, and embedded in resin, cured, sectioned, and contrasted with saturated uranyl acetate and Reynold's lead citrate. Sectioned and stained material was observed with a transmission electron microscope (JEM 1400 Plus, Jeol USA Inc., Peabody, MA) operated at $120 \mathrm{kV}$, and digital images were captured with a Gatan camera (Gatan Inc., Pleasanton, CA).

A second 100-g aliquot of RCM was prepared as described above and then $20 \mu \mathrm{L}$ of chymosin was added. After gently stirring for $30 \mathrm{~s}$, the mixture was immediately poured into 2 Petri dishes to about 1-mm thickness, covered, sealed, and placed in a water bath at $31^{\circ} \mathrm{C}$. At 8 and $24 \mathrm{~min}$ after rennet addition, dishes were taken out from the water bath, slowly flooded with $2 \%$ glutaraldehyde, and fixed in situ for $1 \mathrm{~h}$ at room temperature $\left(\sim 22^{\circ} \mathrm{C}\right)$. Small cubes were cut and handled for electron microscopy as described above.

\section{Statistical Analysis}

Linear regression was performed to investigate the effects of casein level on logarithm of $\mathrm{G}^{\prime}$ and inverse of rennet level on RCT. Effects of coagulation temperature, $\mathrm{pH}$, and rennet level on $\mathrm{G}^{\prime}$ were studied using a completely randomized design. Data were analyzed for statistical significance at $95 \%$ confidence level using PROC GLM function in statistical analysis software (SAS version 9.3, SAS Institute Inc., Cary, NC). Significance was declared at $P<0.05$. Post-hoc means comparisons were made based on $P$-values $(\alpha=0.05)$ using Tukey-Kramer adjustment to obtain differences of least mean squares.

\section{RESULTS AND DISCUSSION}

\section{Factors Influencing Rennet Coagulation}

Casein Level in RCM. Coagulation time of RCM depended $(P<0.05)$ on casein level with casein $\leq 5.7 \%$ (i.e., up to $\sim 2 \times$ concentration) but not at higher concentrations. As casein levels increased from 3.2 to $5.7 \%$, RCT decreased from 8.7 to $7.4 \mathrm{~min}$, but no further decrease was observed as casein levels were increased to
8.4 or $10.9 \%$. The rate of increase of $\mathrm{G}^{\prime}$ in the control milk was slower than in the RCM samples, which could be related to the control containing only $\sim 2.6 \%$ casein. The observed acceleration of rennet coagulation for casein levels up to $\sim 2 \times$ agrees with reports by Sharma et al. (1993), Guinee et al. (1997), and Orme (1998). Others reported no significant effect of UF milk concentration on RCT (Sandra et al., 2011). In the study by Guinee et al. (1997), no further shortening of RCT occurred in UF milk containing more than $3 \%$ protein.

The initial $\mathrm{G}^{\prime \prime}\left(\mathbf{G}^{\prime \prime}{ }_{\mathbf{0}}\right)$ increased about 10 fold $(P<$ $0.05)$ as casein levels were raised from 3.2 to $10.9 \%$, whereas no significant change $(P>0.05)$ in initial $\mathrm{G}^{\prime}$ $\left(\mathbf{G}^{\prime}{ }_{0}\right)$ occurred with a value $<0.1 \mathrm{~Pa}$. Having steeper slopes of $\mathrm{G}^{\prime}$ over time, and less time needed to reach a specified $\mathrm{G}^{\prime}$ value with increasing casein levels, implied a faster increase in $\mathrm{G}^{\prime}$ as casein levels increased (Figure 1). Logarithm of $\mathrm{G}^{\prime}$ at $\mathrm{RCT}\left(\mathbf{G}^{\prime}{ }_{1}, \mathrm{R}^{2}=0.99\right), 1.5$ times of $\operatorname{RCT}\left(\mathbf{G}^{\prime}{ }_{1.5}, \mathrm{R}^{2}=0.94\right)$, and 2 times of $\operatorname{RCT}\left(\mathbf{G}^{\prime}{ }_{\mathbf{2}}\right.$, $\left.\mathrm{R}^{2}=0.95\right)$ were linearly associated with casein level $(P$ $<0.001$, Figure 2). For every percent unit increase of casein level, $\log \mathrm{G}^{\prime}$ increased about 0.2 units.

Increased $\mathrm{G}^{\prime \prime}{ }_{0}$ in RCM with high casein levels indicates an increased viscosity in those samples as expected. Such a relationship has previously been found in UF retentate (Orme, 1998; Sandra et al., 2011). Normally in cheese making, milk starts to coagulate $\sim 20 \mathrm{~min}$ after rennet addition and cheese makers start to cut the curd at $\sim 30$ min (McMahon et al., 1984). Thus, the value of $\mathrm{G}_{1.5}^{\prime}$ indicates curd firmness at 1.5 times of RCT, which is about the cutting time. The value of $\mathrm{G}_{2}{ }_{2}$ is used to compare curd firming rate regardless of

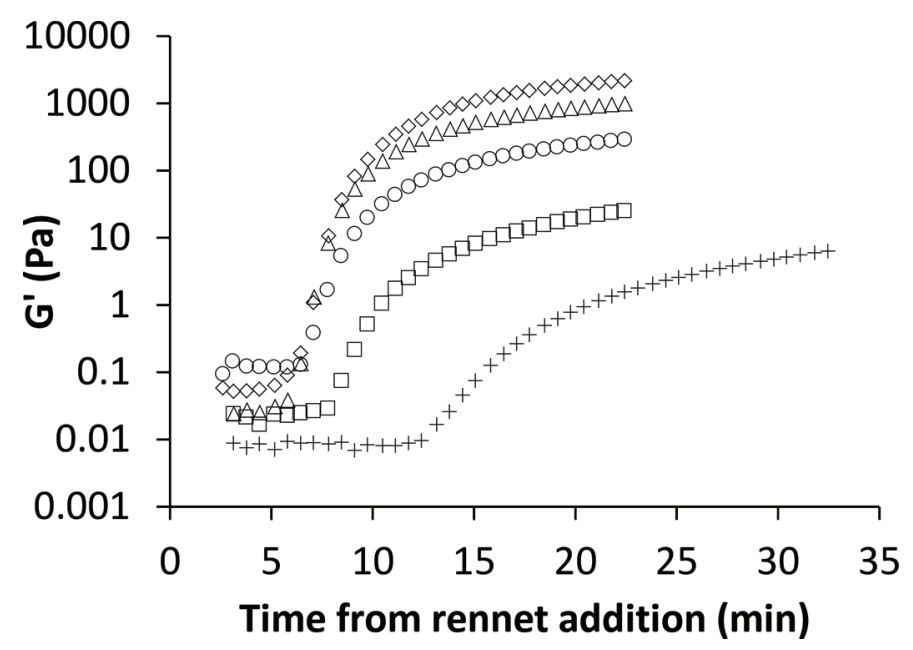

Figure 1. Storage modulus $\left(\mathrm{G}^{\prime}\right)$ of rennet gel of recombined concentrated milk ( $\mathrm{pH} 6.4$ and protein:fat ratio of 0.8 ) at different casein levels: $3.2 \%(\square), 5.7 \%(\bigcirc), 8.4 \%(\Delta)$, and $10.9 \%(\diamond)$, as well as gel of whole milk $(+)$, coagulated at $31^{\circ} \mathrm{C}$ under strain of 0.01 and frequency of $1 \mathrm{~Hz}$. Curves represent means of 3 replicates. 




Figure 2. Linear relationship between logarithm of storage modulus $\left(\mathrm{G}^{\prime}\right)$ of recombined concentrated milk ( $\mathrm{pH} 6.4$ and protein:fat ratio of 0.8 ) at rennet coagulation time $(\bigcirc)$, at 1.5 times of rennet coagulation time $(\square)$, and at 2 times of rennet coagulation time $(\Delta)$, under different casein levels, strain of 0.01 , and frequency of $1 \mathrm{~Hz}$.

rennet levels being used (McMahon and Brown, 1984). The linear relationships between $\mathrm{G}^{\prime}$ and casein levels indicate that curd firmness at coagulation time and cutting time, as well as curd firming rate, all increased with higher casein level in RCM. These results agree with previous observations of increased curd firming rate and curd firmness in concentrated and ultrafiltrated milk (Dalgleish, 1980, 1981; Guinee et al., 1996; Sandra et al., 2011). Guinee et al. (1996) demonstrated a power-law relationship between protein concentration in skim milk UF retentate and $\mathrm{G}^{\prime}$ of rennet curd: $\mathrm{G}^{\prime}$ $\propto \mathrm{P}^{\mathrm{n}}(\mathrm{n}>1)$. They also found a similar relationship between protein concentration and curd firming rate.

It has been suggested that unlike rennet milk curd formed by aggregation of large clusters of macro-peptide-depleted casein micelles, rennet curd made from concentrated milk (e.g., UF or MF milk) is primarily formed by aggregation of small clusters of individual casein micelles at high concentration (Orme, 1998). Instead of the thin strands and highly branched matrix with large whey pockets in rennet milk curd, such small-sized clusters in rennet concentrated-milk curd would be able to interpenetrate and form thick strands with a low degree of branching and small whey pockets, resulting in increased curd firmness in concentrated-milk curd (Orme, 1998). The fast coagulation in concentrated milk is mainly attributed to increased frequency of successful inter-micellar collisions, which results from decreased mean distance between casein micelles in highly concentrated milk (Garnot et al., 1982; Orme, 1998; Sandra et al., 2011).

Coagulation Temperature. Lowering the temperature of RCM when renneted had the expected effect of slowing coagulation. At $25^{\circ} \mathrm{C}$, coagulation took $9.5 \mathrm{~min}$, compared with having an RCT of $7.4 \mathrm{~min}$ at $31^{\circ} \mathrm{C}(P$ $<0.001$, Table 2). Lowering the temperature of RCM increased $\mathrm{G}^{\prime \prime}$ of the $\mathrm{RCM}$ with the largest change occurring between 31 and $28^{\circ} \mathrm{C}$ and a significant difference $(P<0.05)$ being apparent upon further lowering temperature to $25^{\circ} \mathrm{C}$ (Table 2). In Figure 3, a similar decrease in $\mathrm{G}^{\prime}$ is shown, although this did not reach statistical significance. A similar trend was observed at the $\mathrm{RCT}$ with an increase in $\mathrm{G}_{0}^{\prime}$ as temperature was lowered (Table 2). An increase of $\sim 2 \mathrm{~Pa}$ occurred from initial $G^{\prime}$ to $G^{\prime}$ at $R C T$ (defined as the crossover when $\mathrm{G}^{\prime}=\mathrm{G}^{\prime \prime}$ ), and when plotted on a log scale (as in Figure 3 ), this portion of the curve is more easily observed when $\mathrm{G}_{0}^{\prime}$ is very low as occurs at $31^{\circ} \mathrm{C}$. In addition to the overall slowing down of coagulation, a decrease also occurred in the relative curd firming rate as shown by a decrease in $\mathrm{G}_{1.5}^{\prime}$ and $\mathrm{G}_{2}^{\prime}$ with a significant difference observed between $\mathrm{RCM}$ at $31^{\circ} \mathrm{C}$ compared with $25^{\circ} \mathrm{C}$ at twice $\mathrm{RCT}$ with $\mathrm{G}_{2}{ }_{2}$ being lower at $25^{\circ} \mathrm{C}(827 \mathrm{~Pa}$ compared with 1,107 Pa, Table 2).

Previously, it was reported that a decrease in coagulation temperature from 32 to $28^{\circ} \mathrm{C}$ led to an increase in RCT of UF milk, mainly resulting from low hydrophobic interactions of macro-peptide-depleted casein micelles at low temperatures (Sharma et al., 1993). The dependence of RCT on temperature is alleviated as UF milk is more concentrated, probably because of a higher collision rate of casein micelle at a higher protein level (Orme, 1998). Considering the high casein level

Table 2. Effect of coagulation temperature on mean rennet coagulation time (RCT, min), initial storage modulus $\left(\mathrm{G}_{0}^{\prime}, \mathrm{Pa}\right)$, and loss modulus $\left(\mathrm{G}^{\prime \prime}{ }_{0}, \mathrm{~Pa}\right)$ within 4 min after rennet addition, storage modulus at $1,1.5$, and 2 times the RCT $\left(\mathrm{G}_{1}^{\prime}, \mathrm{G}_{1.5}^{\prime}\right.$, and $\mathrm{G}_{2}^{\prime}$ ) of recombined concentrated milk (11\% casein and protein:fat ratio of 0.8 ) under strain of 0.01 and frequency of $1 \mathrm{~Hz}$

\begin{tabular}{lcccccc}
\hline $\begin{array}{l}\text { Temperature } \\
\left({ }^{\circ} \mathrm{C}\right)\end{array}$ & $\begin{array}{c}\mathrm{RCT} \\
(\mathrm{min})\end{array}$ & $\begin{array}{c}\mathrm{G}^{\prime}{ }_{0} \\
(\mathrm{~Pa})\end{array}$ & $\begin{array}{c}\mathrm{G}^{\prime \prime}{ }_{0} \\
(\mathrm{~Pa})\end{array}$ & $\begin{array}{c}\mathrm{G}^{\prime}{ }_{1} \\
(\mathrm{~Pa})\end{array}$ & $\begin{array}{c}\mathrm{G}^{\prime}{ }_{1.5} \\
(\mathrm{~Pa})\end{array}$ & $\begin{array}{c}\mathrm{G}^{\prime}{ }_{2} \\
(\mathrm{~Pa})\end{array}$ \\
\hline 31 & $7.4^{\mathrm{a}}$ & $0.1^{\mathrm{a}}$ & $0.2^{\mathrm{a}}$ & $2.0^{\mathrm{a}}$ & $335.8^{\mathrm{a}}$ & $1,107.2^{\mathrm{b}}$ \\
28 & $8.0^{\mathrm{a}}$ & $0.8^{\mathrm{a}}$ & $1.0^{\mathrm{ab}}$ & $2.8^{\mathrm{ab}}$ & $264.6^{\mathrm{a}}$ & $908.5^{\mathrm{ab}}$ \\
25 & $9.5^{\mathrm{b}}$ & $0.9^{\mathrm{a}}$ & $1.2^{\mathrm{b}}$ & $3.6^{\mathrm{b}}$ & $258.3^{\mathrm{a}}$ & $827.0^{\mathrm{a}}$ \\
\hline
\end{tabular}

${ }^{\mathrm{a}, \mathrm{b}}$ Means with the same superscript letter within the same column were not significantly different, $\alpha=0.05$. 


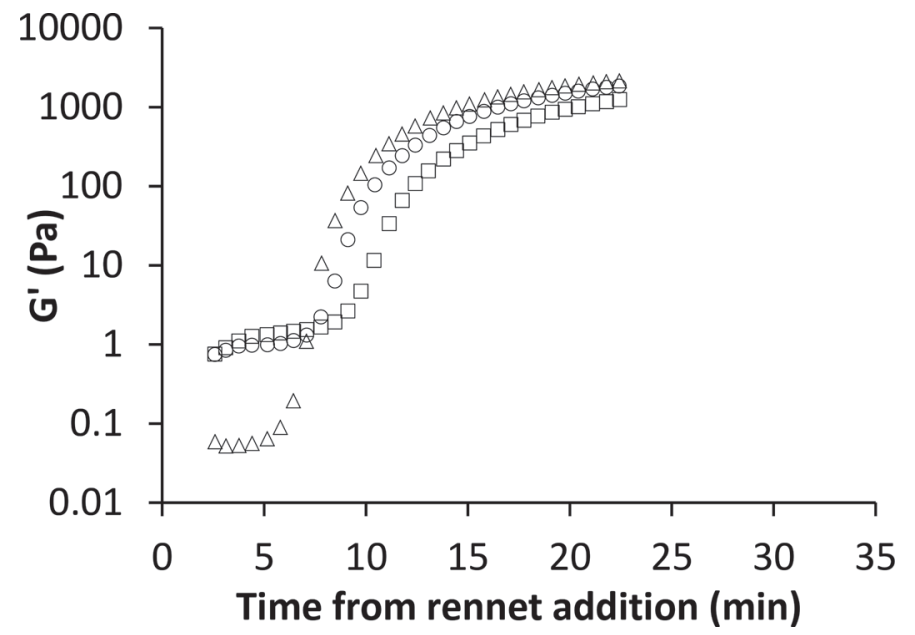

Figure 3. Storage modulus $\left(\mathrm{G}^{\prime}\right)$ of rennet gel of recombined concentrated milk ( $11 \%$ casein and protein:fat ratio of 0.8$)$ coagulated at different temperatures: $31(\Delta), 28(\bigcirc)$, and $25^{\circ} \mathrm{C}(\square)$, under strain of 0.01 and frequency of $1 \mathrm{~Hz}$. Curves represent means of 3 replicates.

in RCM (i.e., 11\%), the mean distance between casein micelles would be further shortened.

The increase of $\mathrm{G}^{\prime \prime}{ }_{0}$ from 31 to $25^{\circ} \mathrm{C}$ indicates that the viscosity of RCM increased with decreased temperature, which was to be expected and happens commonly in fluids. As coagulation temperature was lowered, both $\mathrm{G}_{2}^{\prime}$ (Table 2) and slope of $\mathrm{G}^{\prime}$ curve (Figure 3) were decreasing, implying a reduced curd firming rate. These results are in accordance with Sharma et al. (1993) who showed a decreased curd firming rate in rennetcoagulated UF milk with a decreased coagulation temperature from 32 to $28^{\circ} \mathrm{C}$. The primary reason for a



Figure 4. Storage modulus $\left(\mathrm{G}^{\prime}\right)$ of rennet gel of recombined concentrated milk (11\% protein and protein:fat ratio of 0.8$)$ at different $\mathrm{pH}$ : $6.6(\square), 6.4(\bigcirc)$, and $6.2(\Delta)$, coagulated at $25^{\circ} \mathrm{C}$ under strain of 0.01 and frequency of $1 \mathrm{~Hz}$. Curves represent means of 3 replicates.
Table 3. Effect of $\mathrm{pH}$ on mean rennet coagulation time (RCT, min), initial storage modulus $\left(\mathrm{G}_{0}^{\prime}\right)$, and loss modulus $\left(\mathrm{G}^{\prime \prime}{ }_{0}\right)$ within $4 \mathrm{~min}$ after rennet addition, storage modulus at $1,1.5$, and 2 times the RCT $\left(\mathrm{G}_{1}^{\prime}, \mathrm{G}^{\prime}{ }_{1.5}\right.$, and $\left.\mathrm{G}^{\prime}{ }_{2}\right)$ of recombined concentrated milk (11\% casein and protein:fat ratio of 0.8 ) at $25^{\circ} \mathrm{C}$ under strain of 0.01 and frequency of $1 \mathrm{~Hz}$

\begin{tabular}{lcccccc}
\hline $\mathrm{pH}$ & $\begin{array}{c}\mathrm{RCT} \\
(\min )\end{array}$ & $\begin{array}{c}\mathrm{G}^{\prime}{ }_{0} \\
(\mathrm{~Pa})\end{array}$ & $\begin{array}{c}\mathrm{G}^{\prime \prime}{ }_{0} \\
(\mathrm{~Pa})\end{array}$ & $\begin{array}{c}\mathrm{G}^{\prime}{ }_{1} \\
(\mathrm{~Pa})\end{array}$ & $\begin{array}{c}\mathrm{G}^{\prime}{ }_{1.5} \\
(\mathrm{~Pa})\end{array}$ & $\begin{array}{c}\mathrm{G}^{\prime}{ }_{2} \\
(\mathrm{~Pa})\end{array}$ \\
\hline 6.6 & $11.9^{\mathrm{c}}$ & $0.4^{\mathrm{a}}$ & $1.1^{\mathrm{a}}$ & $3.1^{\mathrm{a}}$ & $110.5^{\mathrm{a}}$ & $342.5^{\mathrm{a}}$ \\
6.4 & $9.5^{\mathrm{b}}$ & $0.9^{\mathrm{a}}$ & $1.2^{\mathrm{a}}$ & $3.6^{\mathrm{a}}$ & $258.3^{\mathrm{b}}$ & $827.0^{\mathrm{b}}$ \\
6.2 & $6.5^{\mathrm{a}}$ & $0.4^{\mathrm{a}}$ & $0.6^{\mathrm{a}}$ & $2.7^{\mathrm{a}}$ & $289.4^{\mathrm{b}}$ & $877.9^{\mathrm{b}}$ \\
\hline
\end{tabular}

${ }^{\mathrm{a}-\mathrm{c}}$ Means with the same superscript letter within the same column were not significantly different, $\alpha=0.05$.

reduced curd firming rate is attributed to decreased hydrophobic interactions of casein micelles, although rennet activity also decreased at lower temperature (i.e., $28^{\circ} \mathrm{C}$; Sharma et al., 1993; Orme, 1998). Although curd firmness at RCT increased at lower temperature, curd firmness at cutting time was not affected.

$p \boldsymbol{H}$. Acidifying RCM from $\mathrm{pH} 6.6$ to 6.2 significantly reduced RCT from 11.9 to $6.5 \mathrm{~min}(P<0.001$, Table $3)$, and increased $(P<0.05) \mathrm{G}_{1.5}^{\prime}$ and $\mathrm{G}_{2}^{\prime}$ from 110 and $340 \mathrm{~Pa}$ to 290 and $880 \mathrm{~Pa}$, respectively. As $\mathrm{pH}$ decreased, rapid increase of $\mathrm{G}^{\prime}$ occurred earlier with a steeper slope (Figure 4). No significant change was observed in $\mathrm{G}_{0}^{\prime}, \mathrm{G}^{\prime \prime}{ }_{0}$, or $\mathrm{G}_{1}^{\prime}(P>0.05$, Table 3$)$.

The changes in $G^{\prime}$ and $G^{\prime \prime}$ indicate that with decreasing $\mathrm{pH}$, both firmness of RCM curd at cutting time and curd firming rate increased, whereas initial $\mathrm{RCM}$ viscosity or curd firmness at RCT remained unchanged. This is similar to reducing $\mathrm{pH}$ of UF concentrated milk from 6.8 to 5.8 producing shorter RCT, while increasing both curd firmness and firming rate

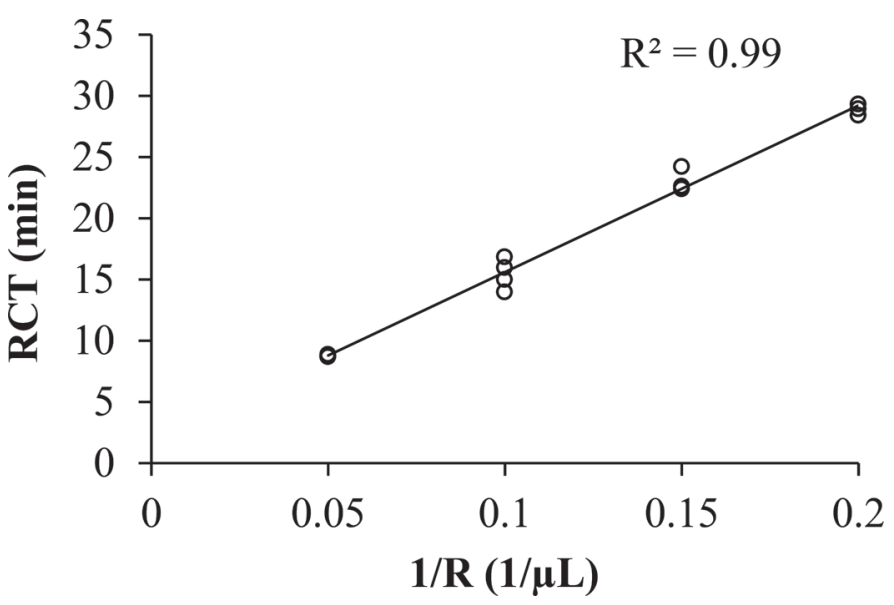

Figure 5. Linear relationship between inverse of rennet $(\mathrm{R})$ level and rennet coagulation time (RCT) in recombined concentrated milk ( $11 \%$ casein and protein:fat ratio of 0.8 ) coagulated at $31^{\circ} \mathrm{C}$ under strain of 0.01 and frequency of $1 \mathrm{~Hz}$. 
(Sharma et al., 1993; Orme, 1998). A similar effect of $\mathrm{pH}$ on curd firming rate has also been reported in regular milk (Kowalchyk and Olson, 1977). Under low pH conditions, reduced zeta-potential of casein micelles in concentrated milk lowers electrostatic repulsion, which then leads to increased collision frequency, resulting in a faster coagulation as evidenced by decreased RCT (Orme, 1998).

Rennet Level. Reducing rennet level from 20 to 5 $\mu \mathrm{L} / 100 \mathrm{~g}$ of mixture (i.e., from 130 to $33 \mathrm{MCU} / \mathrm{kg}$ ) significantly increased RCT from 8.8 to $28.9 \min (P<$ 0.001 ), without any significant changes in $G^{\prime} 1.5$ rate $\mathrm{G}^{\prime} 2(P>0.05$, data not shown). The RCT was linearly associated with inverse of rennet level $\left(P<0.001, \mathrm{R}^{2}\right.$ $=0.99$, Figure 5). As expected, decreasing rennet level increased time required for cleaving $\kappa$-casein and releasing the macro-peptide portion, resulting in increased RCT. No significant effect was found in viscosity, curd firmness, or curd firming rate in renneted RCM curd based on enzyme level, when measured in relationship to RCT (data not shown). A similar inverse relationship between rennet level and RCT was reported in rennet milk coagulation by McMahon and Brown (1983).

\section{Microstructure of RCM}

$\boldsymbol{R} \boldsymbol{C M}$. In low-magnification transmission electron micrographs of RCM ( $11 \%$ casein) fixed at $31^{\circ} \mathrm{C}$, casein micelles were found in loose clusters with presence of fat globules (Figure 6B). Casein micelle distribution was


Figure 6. Transmission electron micrographs of milk ( $\sim 3 \%$ casein, casein:fat ratio of $0.8 ; \mathrm{A}, \mathrm{C}$, and $\mathrm{E})$ and recombined concentrated milk $(\sim 11 \%$ casein, casein:fat ratio of $0.8 ; \mathrm{B}, \mathrm{D}$, and $\mathrm{F})$ glutaraldehyde-fixed at $31^{\circ} \mathrm{C}$ and agarose-solidified at $22^{\circ} \mathrm{C}(\mathrm{f}=\mathrm{fat}$ globules, asterisks $=$ aggregated casein micelles, white arrows $=$ fine protein chains connecting casein micelles, and black arrows $=$ agarose fibers). 

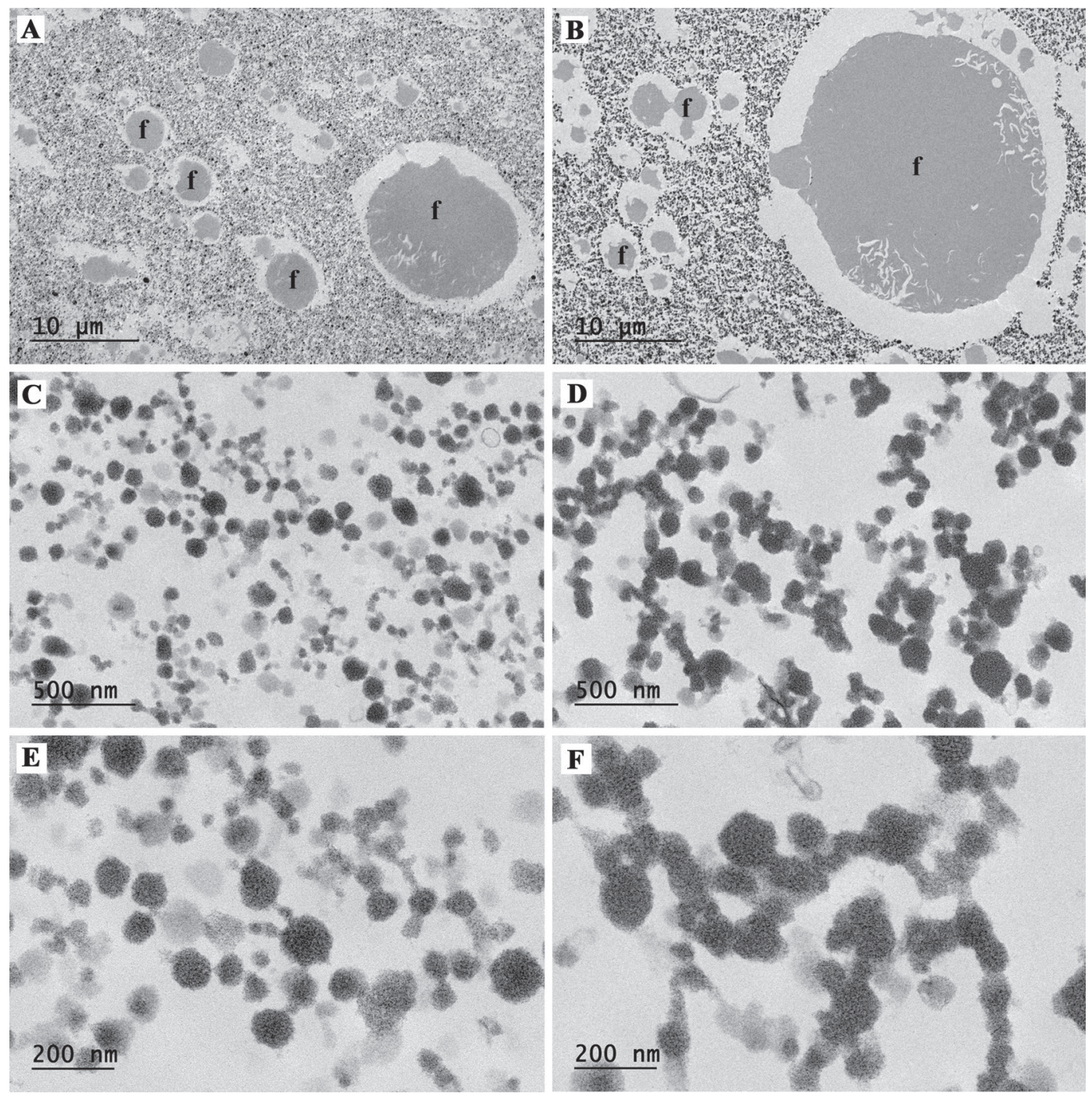

Figure 7. Transmission electron micrographs of rennet coagulum of recombined concentrated milk at $\sim 31^{\circ} \mathrm{C}(\sim 11 \%$ casein, casein:fat ratio of 0.8$)$ at rennet coagulation time $(\mathrm{A}, \mathrm{C}$, and $\mathrm{E})$ and 3 times of rennet coagulation time $(\mathrm{B}, \mathrm{D}$, and $\mathrm{F} ; \mathrm{f}=$ fat globules).

similar in whole milk ( $\sim 3 \%$ casein; Figure $6 \mathrm{~A})$. Casein micelle morphology as observed in high-magnification electron micrographs was typical with many spherical micelles, although some casein micelle aggregates were also found (Figures $6 \mathrm{D}$ and $6 \mathrm{~F}$, asterisks). Individual micelles appeared to be linked to these aggregates by fine protein strands (Figure 6F, white arrows). Overall, casein micelles observed in RCM were comparable to casein micelles in whole milk (Figures 6C and 6F) and in previously examined HC-MCC (Lu et al., 2015). This is in contrast to casein micelles observed in cold-gelled RCM $\left(\sim 12 \%\right.$ casein, at $\left.21^{\circ} \mathrm{C}\right)$, which were less spherical and had a more ragged and open structure. It is possible that with increased temperature (i.e., from 21 to $31^{\circ} \mathrm{C}$ ), there is less dissociation of protein from the casein micelles because of having less solubilization of colloidal calcium phosphate at the higher temperature. We previously observed that casein micelles in RCM were less ragged and more spherical when calcium was added (Lu et al., 2016).

Rennet Coagulum of RCM. The addition of rennet to RCM led to a discernable change in the microstructure of casein micelles. Casein micelles were more spherical than in RCM before adding rennet and they were found aggregated together in strands entrapping fat globules of various sizes (Figure 7A). Compared with protein strands in rennet milk gel as reported previously (Lu et al., 2016), protein strands formed in RCM coagulum were more interlinked. Coagulum of RCM that had formed at 3 times of RCT had even thicker chains of aggregated casein micelles (Figure 7D and $7 \mathrm{~F})$. 
It has been suggested that high levels of casein micelles in UF concentrated milk lead to the formation of smaller casein micelle clusters with a low degree of К-casein hydrolysis during cheese making (Orme, 1998). We found that RCM coagulum had an interlinked and rigid microstructure with both large and small empty spaces located between protein strands, which would very likely result in a stronger network. This agrees with the increased curd firmness $\left(G^{\prime}\right)$ we observed in RCM curd with high protein levels.

\section{CONCLUSIONS}

Understanding rennet coagulation of RCM is necessary for designing processing systems when RCM is used in cheese making. Reducing renneting level can lengthen coagulation time of RCM but does not affect curd firmness or firming rate. Decreased coagulation temperature can lengthen coagulation time and slow curd firming rate, but it also increases initial viscosity of RCM, which might result in the requirement of specialized equipment to handle a RCM with 4 times the normal casein level. The viscosity of RCM is less of a problem at lower concentrations, but even at twice the normal casein level there is a noticeable increase in loss modulus. Concentrating milk using MF has similar effects on RCT as does UF, with no differences in RCT observed for milk containing $\geq 5.7 \%$ casein. While RCT remains similar, the firming rate does increase with casein concentration and the curd has $G^{\prime}$ values 100-fold or more higher than is typical for curd made by renneting milk. When $\mathrm{pH}$ of $\mathrm{RCM}$ was lowered to $\mathrm{pH} 6.2$ before renneting, coagulation was accelerated as well as the rate at which curd firming occurred when measured relative to RCT. Analysis of microstructure of RCM and its coagulum confirmed that the increased curd firmness probably results from a stronger protein matrix formed by highly interlinked protein strands in RCM curd. Overall, RCM with a casein level of 11 to $12 \%$ has potential for use in cheese making provided its higher viscosity compared with milk and its fast curd firming rate can be overcome. Thus, the same problems exist for high casein milks made using MF as those already known for milk concentrated using UF.

\section{ACKNOWLEDGMENTS}

The authors thank Lloyd E. Metzger (South Dakota State University, Brookings) and Anil Kommineni (South Dakota State University) for supplying the HCMCC. We also thank the Aggie Creamery (Utah State University, Logan) for donating of cream and its staff for help with protein measurements, and the Electron Microscopy Core Research Facility at the University of Utah for the use of the transmission electron microscope. Y. Lu was supported in her $\mathrm{PhD}$ studies by the Western Dairy Center, and +MD Inc. (Logan, UT). Funding support was also provided by the Utah Agricultural Experiment Station, Utah State University, and approved as journal paper number 8767 . The use of trade names in this publication does not imply endorsement by Utah State University of the products named or criticism of similar ones not mentioned.

\section{REFERENCES}

Bastian, E. D., K. G. Hansen, and R. J. Brown. 1991. Activation of plasmin with urokinase in ultrafiltered milk for cheese manufacture. J. Dairy Sci. 74:3669-3676.

Brandsma, R. L., and S. S. Rizvi. 2001. Manufacture of Mozzarella cheese from highly concentrated skim milk microfiltration retentate depleted of whey proteins. Int. J. Food Sci. Technol. 36:611624.

Brandsma, R. L., and S. S. H. Rizvi. 1999. Depletion of whey proteins and calcium by microfiltration of acidified skim milk prior to cheese making. J. Dairy Sci. 82:2063-2069.

Burrington, K. J. 2013. Technical report: Milk fractionation technology and emerging milk protein opportunities. U.S. Dairy Export Council, Arlington, VA.

Creamer, L., M. Iyer, and J. Lelievre. 1987. Effect of various levels of rennet addition on characteristics of Cheddar cheese made from ultrafiltered milk. N.Z. J. Dairy Sci. Tech. 22:205-214.

Dalgleish, D. G. 1980. Effect of milk concentration on the rennet coagulation time. J. Dairy Res. 47:231-235.

Dalgleish, D. G. 1981. Effect of milk concentration on the nature of curd formed during renneting-A theoretical discussion. J. Dairy Res. 48:65-69.

Ernstrom, C. A., B. J. Sutherland, and G. W. Jameson. 1980. Cheese base for processing. A high yield product from whole milk by ultrafiltration. J. Dairy Sci. 63:228-234.

Evans, J., J. Zulewska, M. Newbold, M. Drake, and D. Barbano. 2009. Comparison of composition, sensory, and volatile components of thirty-four percent whey protein and milk serum protein concentrates. J. Dairy Sci. 92:4773-4791.

Evans, J., J. Zulewska, M. Newbold, M. A. Drake, and D. M. Barbano. 2010. Comparison of composition and sensory properties of $80 \%$ whey protein and milk serum protein concentrates1. J. Dairy Sci. 93:1824-1843.

Fox, P. F., T. P. Guinee, T. M. Cogan, and P. L. H. McSweeney. 2000. Principal families of cheese. Pages 388-428 in Fundamentals of cheese science. Aspen Publishers Inc., Gaithersburg, MD.

Garem, A., P. Schuck, and J.-L. Maubois. 2000. Cheesemaking properties of a new dairy-based powder made by a combination of microfiltration and ultrafiltration. Lait 80:25-32.

Garnot, P., T. Rank, and N. Olson. 1982. Influence of protein and fat contents of ultrafiltered milk on rheological properties of gels formed by chymosin. J. Dairy Sci. 65:2267-2273.

Govindasamy-Lucey, S., J. Jaeggi, A. Bostley, M. Johnson, and J. Lucey. 2004. Standardization of milk using cold ultrafiltration retentates for the manufacture of parmesan cheese. J. Dairy Sci. $87: 2789-2799$

Govindasamy-Lucey, S., J. J. Jaeggi, M. E. Johnson, T. Wang, and J. A. Lucey. 2007. Use of cold microfiltration retentates produced with polymeric membranes for standardization of milks for manufacture of pizza cheese. J. Dairy Sci. 90:4552-4568.

Guinee, T. P., C. B. Gorry, D. J. O'Callighan, B. R. O'Kennedy, N. O'Brien, and M. A. Fenelon. 1997. The effects of composition and some processing treatments on the rennet coagulation properties of milk. Int. J. Dairy Technol. 50:99-106.

Guinee, T. P., D. J. O'Callaghan, P. D. Pudja, and N. O'Brien. 1996. Rennet coagulation properties of retentates obtained by ultrafil- 
tration of skim milks heated to different temperatures. Int. Dairy J. 6:581-596.

Kosikowski, F. V., A. R. Masters, and V. V. Mistry. 1985. Cheddar cheese from retentate-supplemented whole milk. J. Dairy Sci. $68: 548-554$.

Kowalchyk, A., and N. Olson. 1977. Effects of pH and temperature on the secondary phase of milk clotting by rennet. J. Dairy Sci. 60:1256-1259.

Lelievre, J., L. Creamer, and K. Tate. 1990. Inhibition of calf vell and microbial rennet action by whey protein concentrate. Milchwissenschaft 45:71-75.

Lu, Y., D. J. McMahon, L. E. Metzger, A. Kommineni, and A. H. Vollmer. 2015. Solubilization of rehydrated frozen highly concentrated micellar casein for use in liquid food applications. J. Dairy Sci. 98:5917-5930.

Lu, Y., D. J. McMahon, and A. H. Vollmer. 2016. Investigating cold gelation properties of recombined highly concentrated micellar casein concentrate and cream for use in cheese making. J. Dairy Sci. 99:5132-5143.

McMahon, D. J., and R. Brown. 1983. Milk coagulation time: Linear relationship with inverse of rennet activity. J. Dairy Sci. 66:341344.

McMahon, D. J., and R. J. Brown. 1984. Evaluation of formagraph for comparing rennet solutions. J. Dairy Sci. 65:1639-1642.
McMahon, D. J., R. J. Brown, and C. A. Ernstrom. 1984. Enzymic coagulation of milk casein micelles. J. Dairy Sci. 67:745-748.

Neocleous, M., D. M. Barbano, and M. A. Rudan. 2002a. Impact of low concentration factor microfiltration on milk component recovery and cheddar cheese yield. J. Dairy Sci. 85:2415-2424.

Neocleous, M., D. M. Barbano, and M. A. Rudan. 2002b. Impact of low concentration factor microfiltration on the composition and aging of Cheddar cheese. J. Dairy Sci. 85:2425-2437.

Orme, B. J. 1998. Improving fat retention and texture in low-moisture cheese manufactured from ultrafiltered milk. PhD Diss. Department of Nutrition and Food Sciences, Utah State Univ., Logan.

Sandra, S., C. Cooper, M. Alexander, and M. Corredig. 2011. Coagulation properties of ultrafiltered milk retentates measured using rheology and diffusing wave spectroscopy. Food Res. Int. 44:951-956.

Sharma, S. K., A. R. Hill, and G. S. Mittal. 1993. Effect of milk concentration, $\mathrm{pH}$ and temperature on aggregation kinetics and coagulation properties of ultrafiltered (UF) milk. Food Res. Int. 26:81-87.

St-Gelais, D., M. Piette, and G. Belanger. 1995. Production of Cheddar cheese using milk enriched with microfiltered milk retentate. A preliminary study. Milchwissenschaft 50:614-619. 